\title{
Finger clubbing and regional enteritis
}

\author{
J. F. FIELDING AND W. T. COOKE \\ From the Nutritional and Intestinal Unit, The General Hospital, Birmingham
}

SUMMARY Finger clubbing was present in 105 of $181(58 \%)$ patients. It was related to the activity but not to the site of the disease and disappeared two to three months after the disease became quiescent.

The occurrence of finger clubbing in patients with Crohn's disease was recorded by Mendlowitz (1938). Crohn and Yarnis (1958) found it in four of 222 patients with regional enteritis and in 12 out of 36 patients when the disorder involved the jejunum. Sussman and Wachtel (1954) noted a somewhat similar incidence $(40 \%)$ in 23 patients with jejunoileitis. On the other hand, Cooke (1955) noted that 48 out of 90 patients with varying parts of the small intestine involved had clubbing. Nevertheless, Thayer (1970) stated that the incidence was unknown. This paper therefore considers finger clubbing in regional enteritis (Crohn's disease) and its relationship to the activity of the disease.

\section{Definition of Finger Clubbing}

A description of clubbing was given as early as 1832 by Pigeaux, but the most quoted description is that by Lovibond (1938). This formed the basis of the classification propounded by Lovell (1950) which is used in this paper.

GRADE I: SLIGHT CLUBBING

Increased ballotment with or without hyperaemia of the skin at the base of the nail with some flattening of the dorsal contour of the nail.

\section{GRADE II : MODERATE CLUBBING}

Increased and definite curving of the nail, some enlargement of the pulp with or without ballotment (Fig. 1).

\section{GRADE III: SEVERE CLUBBING}

More marked curvature of the nail in either direction usually with definite enlargement of the pulp of the terminal phalanx and usually with ballotment on the Received for publication 6 April 1971.

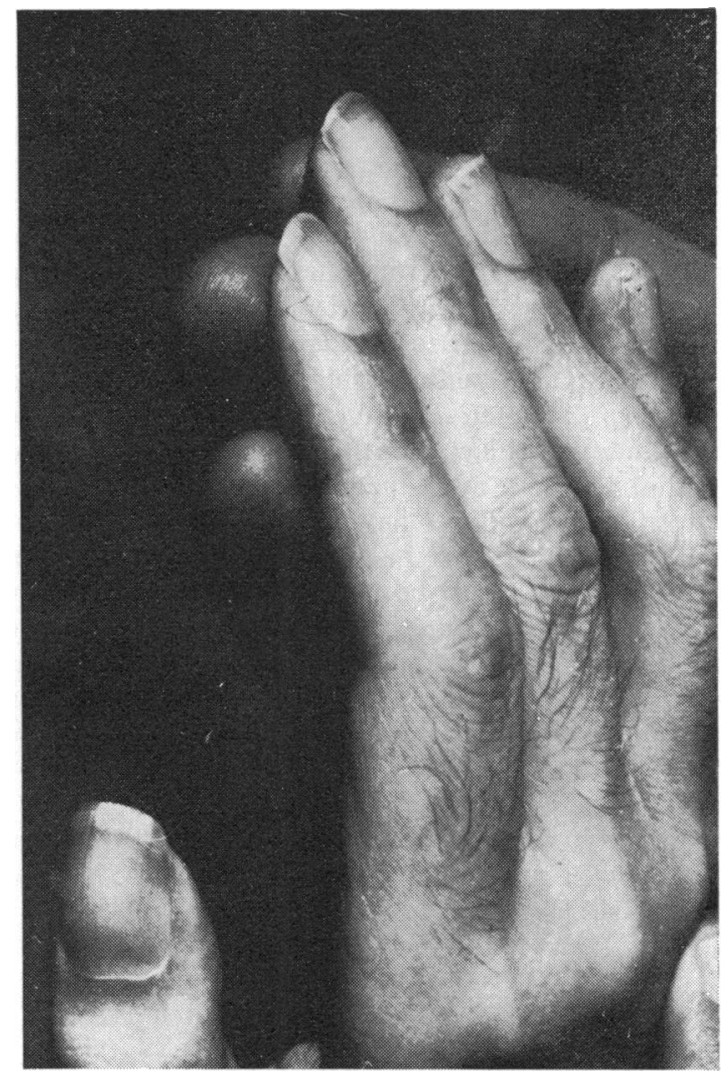

Fig. 1 Grade I and II clubbing shown in thumb, fore, and middle fingers (normal nails in fourth and fifth fingers paralysed after poliomyelitis). The hyperaemic skin at the base of the finger is well shown.

nail bed and hyperaemia of the skin at the base (Fig. 2). 


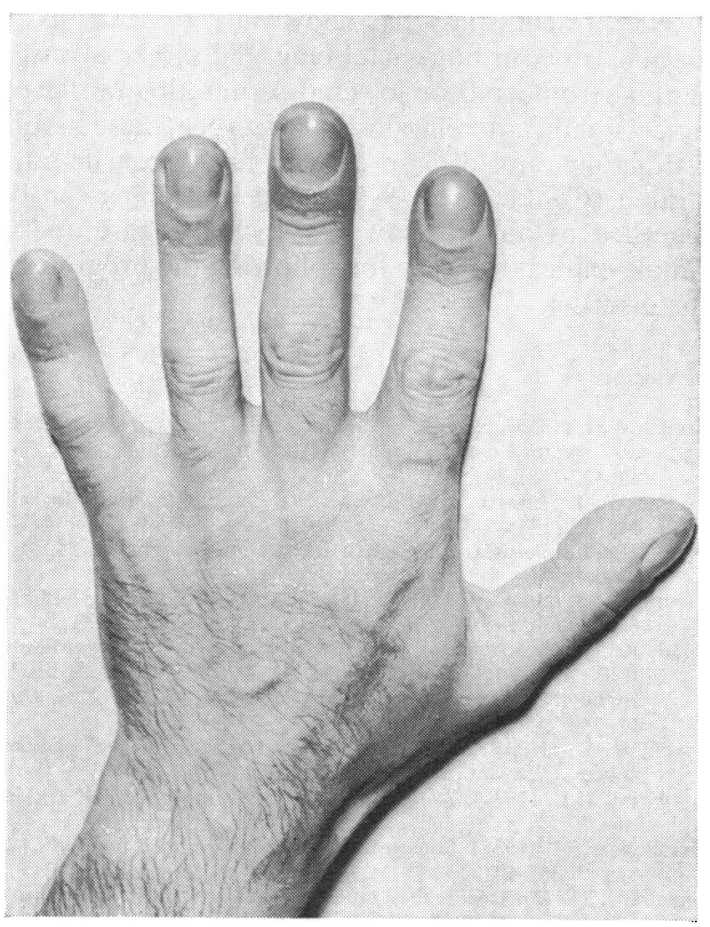

Fig. 2 Grade III clubbing showing increased pulp, curvature of the nail, hyperaemia, and swelling at bases of the nails.

\section{Materials and Methods}

A consecutive series of 181 patients with Crohn's disease (128 with small bowel disease including caecal involvement, 24 with large bowel disease, and
29 with disease involving both large and small bowel) were examined for the presence of finger clubbing at their regular attendance at the Nutritional and Intestinal Unit. At each attendance, blood was examined haematologically and biochemically, including estimates of serum albumin and serum seromucoids (Cooke, Fowler, Cox, Gaddie, and Meynell, 1958).

The relationship between the incidence of clubbing, the area of bowel involved, the serum albumin and serum seromucoids was determined and the statistical significance of the results was calculated by a $\chi^{2}$ analysis.

Three examples are given to illustrate the changes in finger clubbing that occur in the course of the disorder (Table I).

\section{Results}

Finger clubbing was noted in $105(58 \%)$ of the 181 patients, in $69(54 \%)$ of the 128 patients with small bowel disease, in $15(62 \%)$ of the 24 patients with large bowel involvement, and in $20(69 \%)$ of those with combined involvement of the large and small bowels.

The relationship between the presence of finger clubbing and a raised serum seromucoid or decreased albumin level is shown in Table II. There was a significant relationship between the presence of finger clubbing and either a raised level of serum seromucoid or a decreased level of serum albumin for small bowel disease. Expected values of less than 5 prevented a valid statistical analysis for the other two subgroups, but since combining these groups either with the small bowel group or with each other gave $\chi^{2}$ values greater than that for small bowel

\begin{tabular}{|c|c|c|c|c|c|}
\hline Patient & Date & Clinical Features & Clubbing Grade & $\begin{array}{l}\text { Serum Albumin }(g / 100 \mathrm{ml}) \\
(N=4 \cdot 0+)\end{array}$ & $\begin{array}{l}\text { Serum Seromucoid } \\
(m g / 100 m l) \\
(N-<150)\end{array}$ \\
\hline \multirow[t]{4}{*}{$\begin{array}{l}\text { Case 1 } \\
\text { (Female) }\end{array}$} & $\begin{array}{l}\text { Feb. } 1968 \\
\text { March } 1968\end{array}$ & $\begin{array}{l}\text { Pain, lassitude, weight loss } \\
\text { Intestinal resection }\end{array}$ & 3 & $3 \cdot 8$ & 258 \\
\hline & May 1968 & Well & 2 & 4.7 & 132 \\
\hline & July 1968 & Well & 0 & $4 \cdot 2$ & 126 \\
\hline & Oct. 1968 & Well & 0 & $4 \cdot 0$ & 129 \\
\hline \multirow[t]{3}{*}{$\begin{array}{l}\text { Case } 2 \\
\text { (Male) }\end{array}$} & $\begin{array}{l}\text { April } 1968 \\
\text { April } 1968\end{array}$ & $\begin{array}{l}\text { Colic, weight loss, diarrhoea } \\
\text { Intestinal resection }\end{array}$ & 3 & $2 \cdot 4$ & 312 \\
\hline & $\begin{array}{l}\text { Dec. } 1968 \\
\text { Feb. } 1969\end{array}$ & $\begin{array}{l}\text { Improved } \\
\text { ACTH therapy }\end{array}$ & 3 & $3 \cdot 7$ & 228 \\
\hline & $\begin{array}{l}\text { May } 1969 \\
\text { July } 1969\end{array}$ & $\begin{array}{l}\text { Symptom free, weight gain } \\
\text { Symptom free }\end{array}$ & $\begin{array}{l}2 \\
0\end{array}$ & $\begin{array}{l}4.6 \\
4.7\end{array}$ & $\begin{array}{l}126 \\
135\end{array}$ \\
\hline $\begin{array}{l}\text { Case } 3 \\
\text { (Female) }\end{array}$ & $\begin{array}{l}\text { Feb. } 1968 \\
\text { May } 1968 \\
\text { Oct. } 1968 \\
\text { Jan. } 1969 \\
\text { May } 1969\end{array}$ & $\begin{array}{l}\text { Diarrhoea } \\
\text { Improved } \\
\text { Symptom free } \\
\text { Symptom free, marked weight gain } \\
\text { Well }\end{array}$ & $\begin{array}{l}3 \\
3 \\
3 \\
2 \\
1\end{array}$ & $\begin{array}{l}2 \cdot 7 \\
2 \cdot 5 \\
3 \cdot 3 \\
3 \cdot 5 \\
3 \cdot 8\end{array}$ & $\begin{array}{l}312 \\
336 \\
228 \\
204 \\
168\end{array}$ \\
\hline
\end{tabular}

Table I Examples of finger clubbing 
alone, it is likely that too few cases prevented a similarly significant result for each of these two groups.

\begin{tabular}{lllllll}
\hline & \multicolumn{5}{l}{\begin{tabular}{l} 
Number of Patients \\
\cline { 2 - 5 }
\end{tabular}} & \multicolumn{4}{l}{$\begin{array}{l}\text { With } \\
\text { Clubbing } \\
(105)\end{array}$} & $\begin{array}{l}\text { Without } \\
\text { Clubbing } \\
(76)\end{array}$ & & \\
\hline $\begin{array}{l}\text { Seromucoids } \\
\text { (mg/100 ml) }\end{array}$ & $>150$ & 32 & 7 & 10.52 & $<0.001$ \\
& $<150$ & 73 & 69 & & \\
$\begin{array}{l}\text { Serum albumin } \\
\text { (g/100 ml) }\end{array}$ & $>4.0$ & 33 & 6 & 14.5 & $<0.001$ \\
\hline
\end{tabular}

Table II Finger clubbing related to seromucoid and serum albumin levels

\section{Discussion}

The prevalence of finger clubbing in this study was more than $50 \%$ and was in marked contrast to the $5 \%$ reported in ulcerative colitis (Young, 1966: Jalan, Prescott, Walker, Sircus, McManus, and Card, 1970). The clubbing in regional enteritis had been noted in the follow-up clinic for some years (Cooke, 1955), and in particular that gross finger clubbing in severely ill patients might disappear completely when the patient was restored to health. It had also been noted that hyperaemia and swelling at the base of the nails might appear rapidly with either the acute onset or relapse of clinically severe regional enteritis.
The present study has shown a significant association between finger clubbing and either a raised serum seromucoid or lowered serum albumin level. Since significant relationships between these serum estimations and disease activity have been demonstrated (Cooke et al, 1958), finger clubbing can be regarded as an index of activity of disease and a simple clinical measure for following the progress of the disorder.

\section{References}

Cooke, W. T. (1955). Nutritional and metabolic factors in the aetiology and treatment of regional ileitis. Ann. roy. Coll. Surg. Engl., 17, 137-158.

Cooke, W. T., Fowler, D. I., Cox, E. V., Gaddie, R., and Meynell, M. J. (1958). The clinical significance of seromucoids in regional ileitis and ulcerative colitis. Gastroenterology, 34, 910919.

Crohn, B. B., and Yarnis, H. (1958). Regional lleitis, 2nd revised Ed. Grune and Stratton, New York.

Jalan, K. N., Prescott, R. J., Walker, R. J., Sicus, W., McManus, J. P. A., and Card, W. I. (1970). Arthropathy, ankylosing spondylitis and clubbing of fingers in ulcerative colitis. Gut, 11, 748-754.

Lovell, R. R. H. (1950). Observations on the structure of clubbed fingers. Clin. Sci., 9, 299-321.

Lovibond, J. L. (1938). Diagnosis of clubbed fingers. Lancet, 1, 363364.

Mendlowitz, M. (1938). Some observations on clubbed fingers. Clin. Sci., 3, 387-401.

Pigeaux, J. (1832). Recherches nouvelles sur l'étiologie, la symptomatologie et le mécanisme du developpement fusiforme de l'extrémité des doigts. Arch. gen. Med., 28, 174-184.

Sussman, M. L., and Wachtel, E. (1942). Granulomatous jejunoileitis. Radiology, 39, 48-53.

Thayer, W. R. Jr. (1970). Crohn's disease (regional enteritis). A look at the last four years. Scand. J. Gastroent., 5, Suppl. 6, 165-185.

Young, J. R. (1966). Ulcerative colitis and finger-clubbing. Brit. med. J., 1, 278-279. 